\title{
DEVELOPMENT OF VANADIUM OXIDE ZIRCONIUM SILICATE CATALYST FOR REACTION OF PROPANE DEHYDROGENATION
}

\section{Redkina A. V., Konovalova N. D.}

\section{INTRODUCTION}

Light olefins, primarily ethylene and propylene, are large-tonnage base intermediates in the petrochemical industry ${ }^{1}$. They are used in the production of polymers, plastics, synthetic fibers, drugs, rubbers, dyes, detergents, lubricants, high-octane components of motor fuels, solvents and many other products ${ }^{2}$. Most of them are produced in ethylene plants by steam thermal and liquid phase catalytic cracking of products of distillation of crude oil and associated petroleum gases. However, the global demand for propylene significantly exceeds its production volumes by these methods, therefore, in recent years; an alternative "non-oil" technology is developed at a faster pace for the targeted production of propylene by direct catalytic dehydrogenation of propane $(\mathrm{DHP})^{3,4,5,6}$. This is also facilitated by the downward trend in world oil reserves, a drop in the content of propylene in products its making and a significant increase in the production of cheap natural shale gas, which in

${ }^{1}$ Брагинский О.Б. Мировая нефтехимическая промышленность. Москва : Наука, 2003, 556 с.

${ }^{2}$ Новый справочник химика и технолога. Сырье и продукты органических и неорганических веществ. Часть ІІ. СПб. НПО «Профессионал», 2007, 1144 с.

${ }^{3}$ Макарян И.А., Рудакова М.И., Савченко В.И. Промышленные процессы целевого каталитического дегидрирования пропана в пропилен. Междунар. научн. журнал «Альтернативная энергетика и экология». 2010.Т.86, № 6. C. $67-81$

4 Vora B.V. Development of Dehydrogenation Catalysts and Processes. Top. Catal. 2012. V. 55. P. 1297-1308. DOI:10.1007/s11244-012-9917-9

${ }_{5}$ Sattler J.H.B., Ruiz-Martinez J., Santillan-Jimenez E., Weckhuysen B.M. Catalytic Dehydrogenation of Light Alkanes on Metals and Metal Oxides. Chem. Rev. 2014. V. 114, №. 20. P. 10613-10653. https://doi.org/10.1021/cr5002436|

6 Nawaz Z. Light alkane dehydrogenation to light olefin technologies: A comprehensive review.Rev. Chem. Eng. 2015. V. 31, № 5. P. 413-436. https://doi.org/10.1515/revce-2015-0012 
addition to the main methane also contains ethane and propane ${ }^{7}$. An additional advantage of the technology of catalytic dehydrogenation of light alkanes and, in particular, propane, is also the fact that this universal technique, with relatively less investment, allows to obtain high-purity olefins instead of a mixture of products and to ensure co-production of hydrogen:

$$
\mathrm{C}_{3} \mathrm{H}_{8} \leftrightarrow \mathrm{C}_{3} \mathrm{H}_{6}+\mathrm{H}_{2}\left(\Delta \mathrm{H}_{298}^{0}=124,3 \mathrm{~kJ} / \mathrm{mol}\right)
$$

On the other hand, the dehydrogenation of light alkanes C2-C4 is one of the most complex chemical processes for implementation on an industrial scale. These reactions are highly exothermic; therefore, in order to obtain alkane conversion of $\geq 50 \%$ at a pressure of 1 bar, it is necessary to increase the temperature to $550-750^{\circ} \mathrm{C}^{8}$. At these temperatures, the rupture reactions in alkane molecules of a less strong $\mathrm{C}-\mathrm{C}$ bond with the formation of by-products of their cracking and further coke become thermodynami-cally and kinetically more favorable. Catalyst for the dehydrogenation process should predominantly activate the cleavage of $\mathrm{C}-\mathrm{H}$ bonds in alkanes, minimizing and slowing down the process of molecular destruction, including the formation of more reactive olefins. In addition, these reactions are reversible and occur with an increase in the volume of gases; therefore, the maximum degree of alkane conversion is limited by the establishment of thermodynamic equilibrium, which can be shifted towards the formation of the target olefins by lowering the pressure in the system below atmospheric or by reducing the partial pressure of alkanes by diluting with steam or an inert gas.

Many materials have been studied as catalysts for the dehydrogenation of light alkanes and five main production processes have been patented, which differ in the type of reactor, the operating mode, and the catalyst used. These are the processes: Catofin (ABB Lummus Crest/United Catalysts) ${ }^{9}$, Oleflex, firms UOP (US) ${ }^{10}$; STAR

7 McFarland E. Unconventional Chemistry for Unconventional Natural Gas. Science. 2012. V. 338. P. 340-342. DOI: 10.1126/science. 1226840

8 Sattler J.H.B., Ruiz-Martinez J., Santillan-Jimenez E., Weckhuysen B.M. Catalytic Dehydrogenation of Light Alkanes on Metals and Metal Oxides. Chem. Rev. 2014. V. 114, №. 20. P. 10613-10653. https://doi.org/10.1021/cr5002436

${ }^{9}$ Bhatt B.L., Kirner J.F., Rao P. and Schwartz W.A. Catalytic dehydrogenation reactor cycle. Pat. US 4581339, Publ. Apr. 08, 1986

${ }^{10}$ Bricker J.C., Jan D.-Y., Foresman J.M. Dehydrogenation catalyst composition. Pat. US 4914075, Publ. Apr. 03, 1990 
(Phillips Petroleum Company) ${ }^{11}$, FFB - Fluidized Bed Dehydrogenation (Snamprogetti - Yarsintez) ${ }^{12}$ and Linde-PDH BASF ${ }^{13}$. However, in all of these technologies, only two types of catalyst formulations have been proposed: $\mathrm{Cr}_{2} \mathrm{O}_{3}$ supported on $\mathrm{Al}_{2} \mathrm{O}_{3}$ (processes - Catofin and $\mathrm{FFB}$ ) and Pt-Sn alloy, supported on $\mathrm{Al}_{2} \mathrm{O}_{3}$ (Oleflex); spinel $\mathrm{ZnAl}_{2} \mathrm{O}_{4} / \mathrm{CaAl}_{2} \mathrm{O}_{4}$ (STAR) or $\mathrm{ZrO}_{2}$ (Linde-PDH BASF). Currently, Catofin and Oleflex processes are commercialized; dozens DHP plants are working by these technologies and are planned to launching. This, according to forecasts, will lead to the fact that to the end of $2020,20 \%$ of the global needs in propylene will be replaced due to its targeted production from propane ${ }^{14}$. The STAR process will be used for the first time at two facilities in the Middle East ${ }^{15}$.

It is reported ${ }^{16}$ that according to Catofin technology on $\mathrm{Cr}_{2} \mathrm{O}_{3} / \mathrm{Al}_{2} \mathrm{O}_{3}$ at of $590-650{ }^{\circ} \mathrm{C}$ and a pressure of 0,3-0,5 bar, propylene is formed with a selectivity of $82-87 \%$ at a conversion of propane of $48-65 \%$; and in the Oleflex process on $\mathrm{Pt}-\mathrm{Sn} / \mathrm{Al}_{2} \mathrm{O}_{3}$ at $550-620^{\circ} \mathrm{C}, 2-5$ bar and propane conversion of $25-40 \%$, propylene selectivity is $89-91 \%$.

The disadvantage of using chromium oxide as a catalyst for the process is its toxicity due to the significant proportion of the carcinogen $\mathrm{Cr}$ (VI) contained in it after oxidative regeneration ${ }^{17}$. Catalysts containing platinum - Pt-Sn $/ \mathrm{Al}_{2} \mathrm{O}_{3}$, are expensive and, like $\mathrm{Cr}_{2} \mathrm{O}_{3} / \mathrm{Al}_{2} \mathrm{O}_{3}$, are subject to a greater degree of particle agglomeration during temperature increase than the initial alumina. Both catalysts are coked

11 Brinkmeyer F.M., Savage K.B. and Bridges S.D. Dehydrogenation process control Pat US. 5243122, Publ. Sept. 07, 1993.

${ }^{12}$ Iezzi R., Bartolini A., Buonomo F., Kotelnikov G. and Bespalov V. Process for obtaining light olefins by the dehydrogenation of the corresponding paraffins Pat. US 6362385, Publ. March 26, 2002.

${ }^{13}$ Heineke D., Baier M., Demuth D. and Harth K. Method and catalyst for producing olefins, in particular propylenes, by dehydrogenation. Pat. US 6576804 , Publ. June 10, 2003.

14 UOP's PP plant using C3 Oleflex technology starts in China. Feb. 03, 2015 (China). URL :.http://www.fibre2fashion.com News

15 Sattler J.H.B., Ruiz-Martinez J., Santillan-Jimenez E., Weckhuysen B.M. Catalytic Dehydrogenation of Light Alkanes on Metals and Metal Oxides. Chem. Rev. 2014. V. 114, №. 20. P. 10613-10653. URL : https://doi.org/10.1021/ cr5002436.

${ }^{16}$ Макарян И.А., Рудакова М.И., Савченко В.И. Промышленные процессы целевого каталитического дегидрирова-ния пропана в пропилен. Междунар. научн. Жур. «Альтерн. энергетика и экология». 2010. Т. 86, № 6. С. 67-81.

17 Vora B.V. Development of Dehydrogenation Catalysts and Processes. Top. Catal. 2012. V. 55. P. 1297-1308. DOI:10.1007/s11244-012-9917-9. 
during operation and need periodic regeneration, which is carried out by blowing air and steam, in the case of $\mathrm{Cr}_{2} \mathrm{O}_{3}$, or by burning coke followed by reduction of $\mathrm{Pt}$ in a stream of hydrogen. Such treatment leads to a gradual loss of the initial activity of the catalysts, a decrease in their stability, and therefore they must be replaced after 1-3 years of operation $^{18}$. It is proposed to increase the service life of the $\mathrm{Al}_{2} \mathrm{O}_{3}$ support by creating its mixed oxide with $\mathrm{SiO}_{2}$. As the authors of the patent ${ }^{19}$ describe, the chromium oxide catalyst on such carriers exhibits greater thermal stability than the Catofin process catalyst.

\section{The perspective catalysts for propane dehydrogenation}

At the same time, in work ${ }^{20}$, the authors compared the catalyst with isolated groups of vanadium oxide $-\mathrm{VO}_{\mathrm{x}}$, supported on a mesoporous ordered silicate system of the MCM-41 type, with $\mathrm{CrO}_{\mathrm{x}} / \mathrm{MCM}-41$ and the industrial Pt-Sn/ $/ \mathrm{Al}_{2} \mathrm{O}_{3}$ catalyst in the same conditions of work and regeneration. They found that $\mathrm{VO}_{\mathrm{x}} / \mathrm{MCM}-41$ in both oxidized and reduced form showed longer times work in flow and stability in all DHP cycles, its activity could be completely restored by oxidative regeneration, and that significantly exceeded of industrial samples. $\operatorname{In}^{21,22}$, the authors further established that an increase in the acidity of the surface of a silicate support for isolated $\mathrm{VO}_{\mathrm{x}}$ groups by introducing a certain optimal amount of $\mathrm{Al}_{2} \mathrm{O}_{3}$ additives into it promotes the formation of carbon deposition centers active in the dehydrogenation of propane,

18 Sattler J.H.B., Ruiz-Martinez J., Santillan-Jimenez E., Weckhuysen B.M. Catalytic Dehydrogenation of Light Alkanes on Metals and Metal Oxides. Chem. Rev. 2014. V. 114, №. 20. P. 10613-10653. URL : https://doi.org/10.1021/ cr5002436

19 Ruettinger W. and Jacubinas R. Chromia alumina catalysts for alkane dehydrogenation. Pat. US 8895468, Publ. Novem. 25, 2014.

20 Sokolov S., Stoyanova M., Rodemerck U., Linke D., Kondratenko E.V. Comparative study of propane dehydrogenation over V-, Cr-, and Pt-based catalysts: Time on-stream behavior and origins of deactivation. J. Catal. 2012. V. 293. P. 67-75. URL : http://dx.doi.org/10.1016/j.jcat.2012.06.005.

${ }^{21}$ Sokolov S., Stoyanova M., Rodemerck U., Linke D., Kondratenko E.V. Effect of support on selectivity and on-stream stability of surface $\mathrm{VO}_{\mathrm{x}}$ species in nonoxidative propane. Catal. Sci. Technol. 2014. V. 4. P. 1323-1332 URL : https://doi.org/10.1039/C3CY01083J.

${ }_{22}$ Sokolov S., Bychkov V.Yu., Stoyanova M. Rodemerck U., Bentrup U., Linke D., Tyulenin Y.P., Korchak V.N., Kondratenko E.V. Effect of VOx Species and Support on Coke Formation and Catalyst Stability in Nonoxidative Propane Dehydrogenation. ChemCatChem. 2015. V. 7. P. 1691-1700. URL : https://doi.org/10.1002/cctc.201500151. 
increasing the time of stable operation of such a catalyst. $\mathrm{In}^{23}$, it was shown that the modification of MCM-41 by replacing a portion of silicon ions with titanium ions in tetrahedral coordination increases the acidity of its surface and the isolation of supported $\mathrm{VO}_{\mathrm{x}}$ groups, a higher propane conversion during its dehydrogenation to $\mathrm{VO}_{\mathrm{x}} / \mathrm{Ti}-\mathrm{MCM}-41$ and obtaining a higher yield of propylene and hydrogen, compared with $\mathrm{VO}_{\mathrm{x}} / \mathrm{MCM}-41$. The productivity and propylene selectivity achieved at $550{ }^{\circ} \mathrm{C}$ at $5 \% \mathrm{VO}_{\mathrm{x}} / \mathrm{Ti}-\mathrm{MCM}-41$ were close to those obtained on the industrial $\mathrm{Pt}-\mathrm{Sn} / \mathrm{Al}_{2} \mathrm{O}_{3}$ catalyst used in the Oleflex process.

The vanadium oxide catalysts on various oxide supports were tested and showed the greatest activity in the widely studied process of oxidative dehydrogenation of propane (ODHP). Due to the reaction of the interaction of oxygen and hydrogen released during the DHP: $\mathrm{H}_{2}+1 / 2 \mathrm{O}_{2} \rightarrow \mathrm{H}_{2} \mathrm{O}\left(\Delta \mathrm{H}^{0}{ }_{298}=-241,8 \mathrm{~kJ} / \mathrm{mol}\right)$, the total ODHP process becomes substantially exothermic $\left(\mathrm{H}_{298}^{0}=-117,5 \mathrm{~kJ} / \mathrm{mol}\right)$ and is not limited to establishing thermodynamic equilibrium. This gives hope for a reduction in energy consumption for the reaction and an increase in the yield of propylene. However, an analysis of scientific articles published before $2007^{24}$ allowed the authors to conclude that the selectivity for propylene achieved in ODHP under conditions leading to a high conversion of propane is still far from commercial interest. Published modern patents for ODHP also do not show high yields of propylene. Relatively high propylene selectivity for propane ODHP is obtained at a limiting oxygen content, which is almost completely used at elevated reaction temperatures and the process proceeds predominantly by the DHP mechanism. But small oxygen additives in the process of DHP, for example, $\mathrm{O}_{2} / \mathrm{C}_{3} \mathrm{H}_{8}=0,1^{25}$, can increase the propane conversion by $\sim 10 \%$. The authors of ${ }^{26}$ noted that both with ODHP and with DHP, an increase in the yield of propylene can be achieved by increasing the

23 Зажигалов В.А., Коновалова Н.Д., Редькина А.В., Хоменко К.Н. Сравнительное исследование дегидрирования пропана на $\mathrm{VO}_{\mathrm{x}} / \mathrm{MCM}-41$ и $\mathrm{VO}_{\mathrm{x}} / \mathrm{Ti}-\mathrm{MCM}-41$ с получением пропилена и водорода. Укр. хім. журн. 2013. V. 79. № 11. C. 63-72.

${ }^{24}$ Cavani F., Ballarini N., Cericola A. Oxidative dehydrogenation of ethane and propane: How far from commercial implementation? Catal. Today. 2007. V. 127. P.113-131. URL : https://doi.org/10.1016/j.cattod.2007.05.009.

25 Nawaz Z. Light alkane dehydrogenation to light olefin technologies: A comprehensive review.Rev. Chem. Eng. 2015. V. 31, № 5. P. 413-436. URL : https://doi.org/10.1515/revce-2015-0012

${ }^{26}$ Cavani F., Ballarini N., Cericola A. Oxidative dehydrogenation of ethane and propane: How far from commercial implementation? Catal. Today. 2007. V. 127. P. 113-131. URL : https://doi.org/10.1016/j.cattod.2007.05.009. 
surface area of the catalysts and changing their porous structure and chemical nature, which can initiate the additional passing of the hightemperature radical homogeneous reactions. The formation of free radicals in such reactions can occur on the active sites of the surface of the catalysts (heterogeneous onset of homogeneous reactions) and they can be more selective than a completely heterogeneous process.

At present, the supported vanadium oxides are ones of the most promising alternative catalysts for process DHP to propylene without the presence of oxygen in the reaction mixture ${ }^{27}$. Wherein, the onset of the DHP reaction on $\mathrm{VO}_{\mathrm{x}} / \mathrm{Al}_{2} \mathrm{O}_{3}$ authors explain by the formation of propyl radicals associated with vanadium.

As a support, alternative to alumina, for the catalysts of the dehydrogenation light alkanes, the effect of $\mathrm{ZrO}_{2}$ has been studied in sufficient detail. Zirconium dioxide is considered as an ideal support for oxides transition metals ${ }^{28}$. It is chemically stable, inactive in oxidative reactions, has weak amphoteric properties and interacts well with transition metals, contributing to their highly dispersed surface location and inhibiting them sintering. In the DHP the activity of the $\mathrm{Cr}_{2} \mathrm{O}_{3} / \mathrm{ZrO}_{2}$ catalyst was significantly higher than that of the samples of $\mathrm{Cr}_{2} \mathrm{O}_{3}$ supported on $\mathrm{Al}_{2} \mathrm{O}_{3}$ or $\mathrm{SiO}_{2}$. This was explained by the more isolated arrangement of active sites on the surface of zirconium dioxide and the presence of oxygen anionic vacancies involved in the dissociative adsorption of propane ${ }^{29}$. However, the possible relatively large $\mathrm{ZrO}_{2}$ surface $\left(\sim 300 \mathrm{~m}^{2} / \mathrm{g}\right)$, obtained by drying amorphous $\mathrm{Zr}(\mathrm{OH})_{4}$, significantly decreases during its further calcination in air at high temperatures $^{30}$. This is due to the growth and agglomeration of crystallites by the mechanism of surface diffusion and lead to a change in

${ }^{27}$ Liu G., Zhao Z.-J., Wu T., Zeng L., Gong J. Nature of the Active Sites of $\mathrm{VO}_{x} / \mathrm{Al}_{2} \mathrm{O}_{3}$ Catalysts for Propane Dehydrogenation. ACS Catal. 2016.V. 6, № 8. P. 5207-5214. http:// DOI: 10.1021/acscatal.6b00893.

${ }^{28}$ Yamaguchi T. Application of $\mathrm{ZrO}_{2}$ as a catalyst and a catalyst support. Catal. Today. 1994. V. 20. P. 199-217. https://doi.org/10.1016/0920-5861(94)80003-0.

29 DeRossi S., Ferraris, G., Fremoiotti S., Garrone E., Ghiotti G., Campa M.C., Indovina V. Propane Dehydrogenation on Chromia/Silica and Chromia/Alumina Catalysts. J. Catal. 1994, V. 148. P. 36-46. URL : https://doi.org/10.1006/jcat.1994.1183.

${ }^{30}$ Cimino A., Cordischi D., DeRossi S., Ferraris G., Gazzoli D., Indovina V., Minelli G., Occhiuzzi M., Valigi M. Studies on chromia/zirconia catalysts I. Preparation and characterization of the system. J.Catal. 1991. V. 127. P. 744-760. URL : https://doi.org/10.1016/0021-9517(91)90196-B. 
the modifications the formed crystalline $\mathrm{ZrO}_{2}$ phase. It was shown ${ }^{31}$ that the thermostability of $\mathrm{ZrO}_{2}$ can be improved by preliminary dispersing a monolayer of the active component on its surface, which, separating the crystallites of the support from each other, prevents their growth to critical sizes. In this case, a much larger surface area of the catalyst is obtained after the impregnation of zirconia hydrogel with solutions of salts of active elements than when its xerogel is impregnated.

The state of $\mathrm{ZrO}_{2}$ it is stabilizes and under the synthesis of its mixed oxide with $\mathrm{SiO}_{2}{ }^{32}$. This allows not only to create a support with a developed surface and porous structure, but also with a greater strength of acid sites active in $\mathrm{DH}$ processes ${ }^{33}$. The chromium-containing zirconium-silicate xerogels $\mathrm{Cr} / \mathrm{Si} / \mathrm{Zr} / \mathrm{O}$ were tested as catalysts for $\mathrm{DHP}$ and it was shown ${ }^{34}$ that they are much more active at lower temperatures, in comparison with $\mathrm{Cr} / \mathrm{Si} / \mathrm{Al} / \mathrm{O}$, and exhibit $100 \%$ selectivity to propylene. It should be noted that recently, zirconia promoted by metal oxides, increasing the number of active structural anionic vacancies, is considered as an alternative type of unconventional catalysts with a defective structure, capable of replacing spent catalysts for non-oxidative dehydrogenation of light alkanes containing $\mathrm{Cr}$ or $\mathrm{Pt}^{35,36}$.

Based on the positive results obtained in the process of DHP on vanadium oxide supported on Ti-MCM-41 and Cr-containing zirconium

${ }^{31}$ Zhao B.Y., Xu X.P., Ma H.R., Sun D.H., Gao J.M. Monolayer dispersion of oxides and salts on surface of $\mathrm{ZrO}_{2}$ and its application in preparation of $\mathrm{ZrO}_{2}$ supported catalysts with high surface areas. Catal. Letters. 1997. V. 45. P. 237-244. URL : https://doi.org/10.1023/A:1019048503124.

32 del Monte F., Larsen W., Mackenzie J.D.: J Stabilization of Tetragonal $\mathrm{ZrO}_{2}$ in $\mathrm{ZrO}_{2}-\mathrm{SiO}_{2}$ Binary Oxides. Am. Chem. Soc. 2000. V. 83. P. 628-634. URL : https://doi.org/10.1111/j.1151-2916.2000.tb01243.x.

33 Tanabe K., Yamaguchi T. Acid-base bifunctional catalysis by $\mathrm{ZrOa}$ and its mixed oxides. Catal. Today. 1994. V. 20. P. 185-197. URL : https://doi.org/10.1016/0920-5861(94)80002-2.

34 Fujdala K.L., Tilley T.D. Thermolytic molecular precursor routes to $\mathrm{Cr} / \mathrm{Si} / \mathrm{Al} / \mathrm{O}$ and $\mathrm{Cr} / \mathrm{Si} / \mathrm{Zr} / \mathrm{O}$ catalysts for the oxidative dehydrogenation and dehydrogenation of propane. J. Catal. 2003. V. 218. P. 123-134. URL : https://doi.org/10.1016/S0021-9517(03)00141-6.

35 Otroshchenko T., Bulavchenko O., Thanh H. V., Rabeah J., Bentrup U., Matvienko A., Rodemerck U., Paul B., Kraehnert R., Linke D., Kondratenko E.V. Controlling activity and selectivity of bare $\mathrm{ZrO} 2$ in non-oxidative propane dehydrogenation. Appl.Catal. A: Gen. 2019. V. 585. P. 117189-117199. URL : https://doi.org/10.1016/j.apcata.2019.117189.

${ }^{36}$ Jeon N., Choe H., Jrong B., Yun Y. Cu-promoted zirconia catalysts for nonoxidative propane dehydrogenation. Appl.Catal. A: Gen. 2019. V. 586. P. 117211117219. URL : https://doi.org/10.1016/j.apcata.2019.117211. 
silicate xerogel in the previous work $^{37}$, we studied the properties of the micro-mesopores zirconium-silicate $(\mathrm{Zr}-\mathrm{Si})$ xerogels, which also modified with titanium dioxide ( $\mathrm{Zr}-\mathrm{Si}(\mathrm{Ti})$ ), qua as supports of vanadium oxide for DHP catalysts. It was shown that on $\mathrm{V}_{2} \mathrm{O}_{5} / \mathrm{Zr}-\mathrm{Si}$ and $\mathrm{V}_{2} \mathrm{O}_{5} / \mathrm{Zr}-\mathrm{Si}(\mathrm{Ti})$, at a shorter contact time of the reaction mixture, the higher propylene yield was obtained than on $\mathrm{V}_{2} \mathrm{O}_{5} / \mathrm{Ti}-\mathrm{MCM}-41$, which has a structure with regular hexagonal packing of cylindrical mesopores of the same diameter. But under a longer contact time, after $550{ }^{\circ} \mathrm{C}$, the propylene yield on vanadium-zirconium-silicate catalysts became lower. It was concluded that the system of tortuous micro-mesopores of the $\mathrm{Zr}-\mathrm{Si}$ xerogel can impede the development of the DHP reaction by a heterogeneous-homogeneous mechanism.

In this work, the task was set to increase the specific surface, change the porous structure of the $\mathrm{V}_{2} \mathrm{O}_{5} / \mathrm{Zr}-\mathrm{Si}$ and $\mathrm{V}_{2} \mathrm{O}_{5} / \mathrm{Zr}-\mathrm{Si}(\mathrm{Ti})$ catalysts, and determine the influence of these parameters on reaction of the propane dehydrogenation.

\section{Experimental part}

Spherically granular highly dispersed porous $\mathrm{ZrO}_{2}-\mathrm{SiO}_{2}$ oxide was obtained by methods, of the direct sol-gel synthesis and the droplet coagulation of the zirconium silicate hydrogel ${ }^{38}$, using the aqueous solutions of the accessible salts of element, with concentrations necessary for the obtaining the $\mathrm{Zr} / \mathrm{Si}=0.6$ ratio in the synthesis sol, according to the following reactions:

$$
\begin{gathered}
2 \mathrm{~K}_{2} \mathrm{CO}_{3}+\mathrm{ZrOCl}_{2} \rightarrow \mathrm{K}_{2}\left[\mathrm{ZrO}\left(\mathrm{CO}_{3}\right)_{2}\right], \\
\mathrm{K}_{2}\left[\mathrm{ZrO}\left(\mathrm{CO}_{3}\right)_{2}\right]+\mathrm{Na}_{2} \mathrm{SiO}_{3} \rightarrow \mathrm{ZrO}_{2} \cdot \mathrm{SiO}_{2} \cdot \mathrm{n} \mathrm{H}_{2} \mathrm{O}
\end{gathered}
$$

A solution of the zirconium carbonate complex at a rate of $164 \mathrm{ml} / \mathrm{min}$. and a sodium metasilicate solution at a rate of $100 \mathrm{ml} / \mathrm{min}$, was fed to a flow reactor in which the solutions were mixed to form a mixed sol of zirconium oxyhydrate and silicic acid. The sol stream was directed into a column filled with two layers of liquids. The top layer is

37 Редькина А.В., Коновалова Н.Д., Кравченко Н.В., Стрелко В.В. Дегидрирование пропана в пропилен на $\mathrm{V}_{2} \mathrm{O}_{5}$, нанесенном на микромезопористую систему оксидов $\mathrm{ZrO}_{2}-\mathrm{SiO}_{2}-\mathrm{TiO}_{2}$.Укр. хім. журн. 2018. Т. 84, № 7 . С. $43-59$.

38 Яковлев И.І., Стрелко В.В., Кравченко М.В. Золь-гель спосіб одержання сферично гранульованого високо поруватого цирконій силікату. Опис до патенту на корисну модель. UA 105999 U, опубл. 10.04.2016, Бюл. № 7. 
undecane, and the bottom is running tap water. During the passage of the undecane layer $(1.0-1.5 \mathrm{~m}$.), The sol droplets turned into spherical granules of Zr-Si hydrogel, which were transported by water and first fell onto a sieve, and then into a container where they were washed with distilled water from alkalis, salts and traces of undecane. Excess external moisture was carefully removed from the gel spheres, dried at $130^{\circ} \mathrm{C}$, determining the moisture capacity of the hydrogel matrix.

The modification of $\mathrm{Zr}$-Si oxide with titanium dioxide was carried out by adding a $\mathrm{TiCl}_{4}$ solution to the synthesis gel${ }^{39}$ so that the amount of added $\mathrm{TiO}_{2}$ was 3 wt. $\%$ from mass $\mathrm{SiO}_{2}$. This value was chosen for comparison, as the maximum amount of titania that can be introduced into the MCM-41 system without destroying its structure ${ }^{40}$. The molar ratio of $\mathrm{ZrO}_{2} / \mathrm{SiO}_{2} / \mathrm{TiO}_{2}$ oxides in the gel was 0.6/1/0.02. The granules of the hydrogel sample were designated $\mathrm{Zr}-\mathrm{Si}(\mathrm{Ti})$.

Since compounds containing tetravalent $\mathrm{V}$ show a high degree of vanadium incorporation into the porous silicate matrix ${ }^{41}$, vanadium oxide was supported on $\mathrm{Zr}$-Si hydrogels from solution of $\mathrm{VOSO}_{4}$ salt. The hydrogel spheres without external moisture were poured with a $10 \%$ solution of $\mathrm{VOSO}_{4}$ in an amount not exceeding the moisture capacity of the hydrogel matrix, so that $\sim 8 \% \mathrm{~V}$ was residue on the support after drying, The sample was left for two days in order to the vanadium salt diffused into the gel spheres. Then, draining the excess liquid, it was flooded by a solution of $\mathrm{NH}_{4} \mathrm{OH}$ so that ammonia precipitated vanadium hydroxide in the pores of the support. A part of the hydrogel spheres then was dried and calcined in air at $450{ }^{\circ} \mathrm{C}$.

The other part spheres of hydrogel with supported vanadium oxide was placed in steel autoclave and subjected to hydrothermal treatment (HTT) at $250{ }^{\circ} \mathrm{C}$ for 5 hours. This treatment helps to strengthen the bond of the gels elements in their polymer framework and can lead to the production of xerogels with a larger specific surface and pore volume after calcination ${ }^{42}$. Then the samples was removed from the autoclave

39 Редькіна А.В., Коновалова Н.Д., Стрелко В.В. Способ одержання каталізатора дегідрування пропану в пропілен. Опис до патенту на корисну модель UA 131758 U, опубл. 25.01.2019, бюл. № 2 .

40 Koyano K.A., Tatsumi T. Synthesis of titanium-containing MCM-41. Microporous Material. 1997. V. 10: P. 259-271. https://doi.org/10.1016/S09276513(97)00016-3.

${ }^{41}$ Selvam P., Dapurkar S.E. The effect of vanadium sources on the synthesis and catalytic activity of VMCM-41// J. Catal. - 2005. - Vol. 229. - P. 64-71. URL : http://dx.doi.org/10.1016/j.jcat.2004.10.005

${ }^{42}$ Raju V., Jaenicke S., Chuah G.-K. Effect of hydrothermal treatment and silica on thermal stabilityë and oxygen storage capacity of ceria-zirconia. Appl. Catal. B. 2009. V. 91. P. 92-100 https://doi.org/10.1016/j.apcatb.2009.05.01 
and one of its parts was decanted with alcohol and left under it for 12 hours. Thereplacing intermicellar water in hydrogels with alcohol or another organic liquid with a low surface tension, which reduces of force compression of the capills in the gel skeleton during drying, leads to an increase in the volume and pore diameter of the obtained samples ${ }^{43}$. After that, both parts of the samples after HTT were dried and calcined. All the prepared samples were designated as $\mathrm{V}-\mathrm{Zr}-\mathrm{Si}$ and $\mathrm{V}-\mathrm{Zr}-\mathrm{Si}(\mathrm{Ti})$.

Isotherms of low temperature nitrogen adsorption were measured according to the standard procedure on an ASAP 2405 N Micromeritics instrument, after vacuum treatment at $200{ }^{\circ} \mathrm{C}$. The pore size distribution of the radii was calculated using the DFT density functional theory.

An analysis of the microstructure and elemental composition of the obtained catalysts was determined by scanning electron microscopy (SEM) using a JEOL JSM 7001F scanning electron microscope with an Oxford Instruments microanalyzer system.

X-ray diffraction patterns were recorded on a DRON-4-07 diffractometer using $\mathrm{Cu}$ Kó radiation from the anode line with a Ni filter in the reflected beam with Bragg - Brentano geometry.

The DHP reaction was carried out in a flowing quartz reactor $30 \mathrm{~cm}$ long, $0,7 \mathrm{~cm}$ in diameter, using $0,85 \mathrm{~g}$ catalyst weights with a volume of $1 \mathrm{~cm}^{3}$ placed in the middle of the reactor. The flow of the working mixture containing 7 vol. \% propane in argon, was maintained at $18 \mathrm{ml} / \mathrm{min}$ and its contact time with the catalyst $(\tau) 3.5 \mathrm{~s}$. After holding the samples in the reaction mixture for at least an hour at $250-300^{\circ} \mathrm{C}$, the temperature of the reactor was increased by $25^{\circ} \mathrm{C}$ every 30 minutes to $650-675^{\circ} \mathrm{C}$. Propane and the products of its dehydrogenation reaction propylene $\left(\mathrm{C}_{3} \mathrm{H}_{6}\right)$, methane, ethane, and ethylene $\left(\mathrm{C}_{\mathrm{x}} \mathrm{H}_{\mathrm{y}}\right)$ were analyzed on a chromatographic column, filled with silica gel, using a flame ionization detector. The catalytic parameters were determined as the degree of propane conversion - $\mathrm{X}\left(\mathrm{C}_{3} \mathrm{H}_{8}\right)$, product selectivity $-\mathrm{S}\left(\mathrm{C}_{3} \mathrm{H}_{6}\right)$, $\mathrm{S}\left(\mathrm{C}_{\mathrm{x}} \mathrm{H}_{\mathrm{y}}\right)$ and propylene yield - $\mathrm{Y}\left(\mathrm{C}_{3} \mathrm{H}_{6}\right)$

\section{Results and discussion}

The general texture parameters of the obtained catalysts are given in the table 1.

${ }^{43}$ He X., Zhang H., Li Y., Hong Ch., Zhao J. Preparation and Structural Characterization of $\mathrm{SiO} 2-\mathrm{ZrO} 2$ Aerogels. Key Eng. aterials. 2007. V. 336-338. P. 2282-2285. URL : https://doi.org/10.4028/www.scientific.net/KEM.336-338.2282 
Table 1

Textural parameters $\mathrm{V}-\mathrm{Zr}-\mathrm{Si}$ and $\mathrm{V}-\mathrm{Zr}-\mathrm{Si}(\mathrm{Ti})$

\begin{tabular}{|c|c|c|c|c|c|}
\hline Sample & $\begin{array}{l}\text { Sequential } \\
\text { processing }\end{array}$ & $\begin{array}{c}\text { Specific } \\
\text { surface area } \\
\mathrm{S}_{\mathrm{BET}} \mathbf{m}^{2} / \mathrm{g} \\
\end{array}$ & $\begin{array}{c}\text { Total pore } \\
\text { volume } \\
\mathrm{V}_{\Sigma}, \mathrm{cm}^{3} / \mathrm{g} \\
\end{array}$ & $\begin{array}{c}\text { Diameter } \\
\text { mesopore } \\
D_{\text {DFT }}, A^{0} \\
\end{array}$ & $\begin{array}{c}\text { Average } \\
\text { pore } \\
\text { diameter }, \mathbf{A}^{0} \\
\end{array}$ \\
\hline $\mathrm{V}-\mathrm{Zr}-\mathrm{Si}$ & $\mathrm{D}, \mathrm{C}$ & 234 & 0,1699 & 50,86 & 29,04 \\
\hline V-Zr-Si(Ti) & $\mathrm{D}, \mathrm{C}$ & 250,9 & 0,184 & 50,86 & 29,34 \\
\hline $\mathrm{V}-\mathrm{Zr}-\mathrm{Si}$ & HTT, D, C & 303,7 & 0,4834 & 70,32 & 63,66 \\
\hline V-Zr-Si(Ti). & HTT, D, C & 303,1 & 0,4341 & 70,32 & 57,3 \\
\hline $\mathrm{V}-\mathrm{Zr}-\mathrm{Si}$ & HTT, DE, D, C & 358,1 & 0,7056 & 81,44 & 78,82 \\
\hline V-Zr-Si(Ti). & HTT, DE, D, C & 316,5 & 0,6571 & 81,44 & 83,04 \\
\hline
\end{tabular}

${ }^{*}$ - drying $-D$, calcination $-C$, hydrothermal treatment, $-H T T$, decantation with ethanol $-D E$

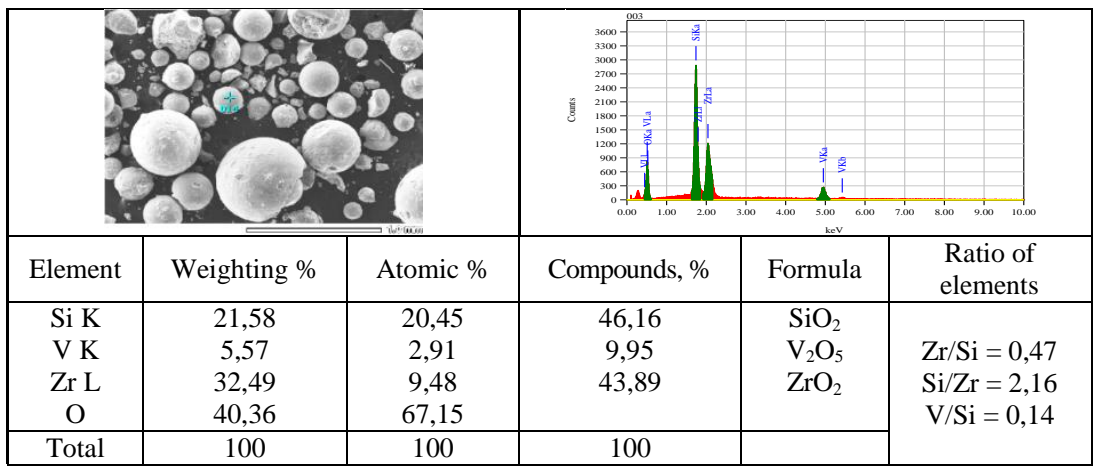

a)

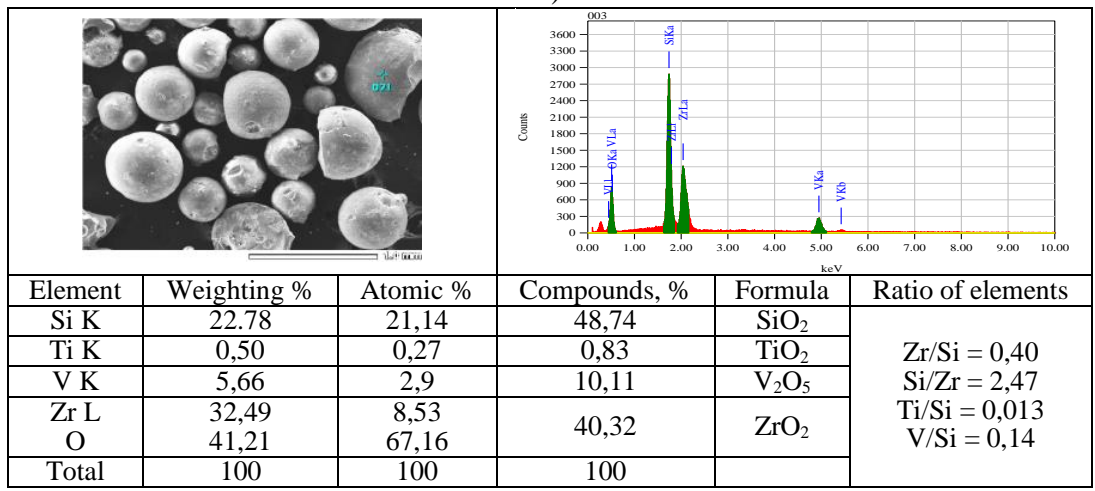

b)

Fig. 1. Image of SEM. Electronic spectra and tables of elements distribution for sample of dried and calcined hydrogels $\mathrm{V}-\mathrm{Zr}-\mathrm{Si}(a)$ and $\mathrm{V}-\mathrm{Zr}-\mathrm{Si}(\mathrm{Ti})(b)$ 
As can be seen from the table, the sequential hydrothermal treatment of the hydrogels of the samples impregnated with the vanadyl sulfate salt and their additional decantation with ethanol leads to an increase in the specific surface area, volume, and pore width of the obtained catalysts. Fig. 1 shows of image catalysts and results of the quantitative measurement contents of elements in their the surface layer as defined by scanning electron microscopy for samples, obtained by supporting of vanadium oxide on wet hydrogels $\mathrm{Zr}$-Si and $\mathrm{Zr}$-Si (Ti) after them drying and calcining. It is also seen that the amount of $\mathrm{ZrO}_{2}$ in the obtained catalysts is less than it was in the sol of synthesis and corresponds to a $\mathrm{Zr} / \mathrm{Si}$ ratio of $\sim 0.4-0.47$ and the $\mathrm{SiO}_{2}$ content in mixed oxides is higher than $\mathrm{ZrO}_{2}$. The average amount of supported vanadium oxide in both catalysts is approximately $10 \mathrm{wt} . \% \mathrm{~V}_{2} \mathrm{O}_{5}$. The average $\mathrm{Si} / \mathrm{Zr}$ ratio in both samples is $2.16-2.47$, this is close to 2, which, according to the Tanabe rule, approximately corresponds to the maximum Brainsted acidity of mixed $\mathrm{ZrO}_{2}-\mathrm{SiO}_{2}$ oxides and theirs the Hammett acidity function can be $\mathrm{H}_{0} \geq-8.2^{44}$.

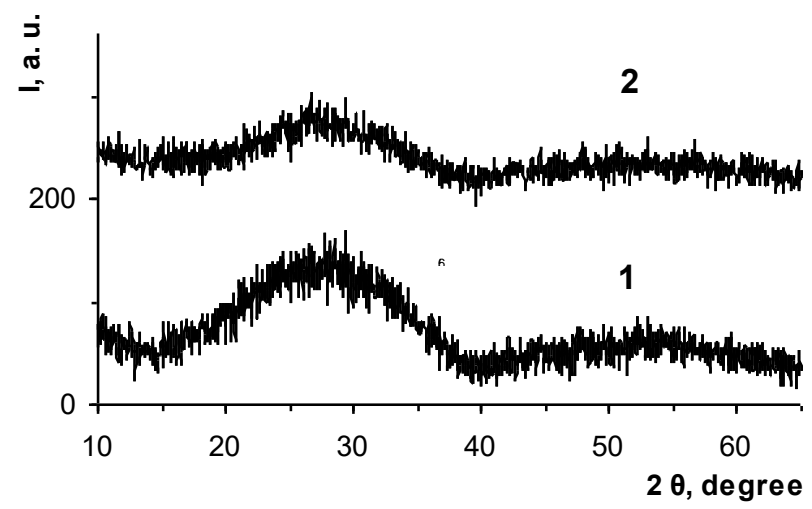

Fig. 2. X-ray diffraction patterns samples:

of $\mathrm{V}-\mathrm{Zr}-\mathrm{Si}-1$ and $\mathrm{V}-\mathrm{Zr}-\mathrm{Si}(\mathrm{Ti})-2$

${ }^{44}$ Bosman, H.J.M., Kruissink, E.C., Van der Spoel, J., Van den Brink, F.: Characterization of the acid strength of $\mathrm{ZrO} 2 \mathrm{SiO} 2$ mixed oxides. J. Catal. 1994, V. 148. P. 660-672. URL : https://doi.org/10.1006/jcat.1994.1253. 
X-ray phase analysis carried out in the range of reflection angles $2 \theta=10-70^{\circ}$ for these synthesized catalysts (Fig. 2), showed the presence of only an amorphous halo on the diffraction patterns of samples. The absence of phase reflections of vanadium oxides may indicate their highly dispersed state on the surface of supports. The absence of phase reflections of metastable tetragonal zirconium dioxide $\mathrm{t}-\mathrm{ZrO}_{2}$, which usually appears already at $400{ }^{\circ} \mathrm{C}$ upon calcination of the dried hydrogel $\mathrm{ZrO}_{2}{ }^{45}$ is consistent with the data, which showed that the amorphous $\mathrm{SiO}_{2}$ matrix, at its content $\geq 50 \%$ in binary oxide $\mathrm{ZrO}_{2}-\mathrm{SiO}_{2}$, contributes to the preservation of the amorphous state of $\mathrm{ZrO}_{2}$ to high calcination temperatures ${ }^{46}$.

Nitrogen adsorption / desorption isotherms of catalysts, obtained by drying and calcining vanadium-containing hydronels (Fig. 3, a) belong to type IV isotherms with $\mathrm{H} 2$ hysteresis loops ${ }^{47}$. The desorption branch in isotherms has a rather large horizontal part, characteristic of corpuscular systems, the pores of which are of an indefinite nature with narrow "throats" and various wider cavities. This is also confirmed by distribution of pores by radius sizes characteristic of micro-mesoporous systems (Fig. 3, b). In this case, the texture parameters of the sample, modified with titanium dioxide, show large values of the specific surface area and volume of pores (table).

The HTT of V-Zr-Si and V-Zr-Si(Ti) hydrogels before their calcining (Fig. 4) changes the shape of the hysteresis loop on the isotherms - the horizontal parts on the desorption branchs becomes shorter, indicating that the difference between the diameters of the "throats" and "cavities" in the porous structure of the catalyst decreases and the type of the hysteresis loop H2 transforms into H1, which is typical for systems with a developed mesoporous structure. Decantation of the sample with ethanol after HTT leads to a narrowing of the shape of the hysteresis loop on the isotherms, indicating an additional equalization of sizes pore radiuses.

${ }^{45}$ Li M., Feng Z., Xiong G. Ying P., Xin Q., and Li C. Phase Transformation in the Surface Region of Zirconia Detected by UV Raman Spectroscopy. J. Phys. Chem. B, 2001, V.105. P. 8107-8111. https://doi.org/10.1021/jp0105261

${ }^{46}$ del Monte F., Larsen W., Mackenzie J.D.: J Stabilization of Tetragonal $\mathrm{ZrO}_{2}$ in $\mathrm{ZrO}_{2}-\mathrm{SiO}_{2}$ Binary Oxides. Am. Chem. Soc. 2000. V. 83. P. 628-634. https://doi.org/10.1111/j.1151-2916.2000.tb01243.x.

${ }^{47}$ Sing K. S. W., Everett D. H., Haul R. A. W., Moscou L., Pierotti R. A., Rouquerol J. and Siemieniewska T. Reporting Physisorption Data for Gas/Solid Systems with Special Reference to the Determination of Surface Area and Porosity. Pure and Applied Chemistry. 1985. V. 57, No. 4. P. 603-619. https://doi.org/10.1351/pac198254112201 

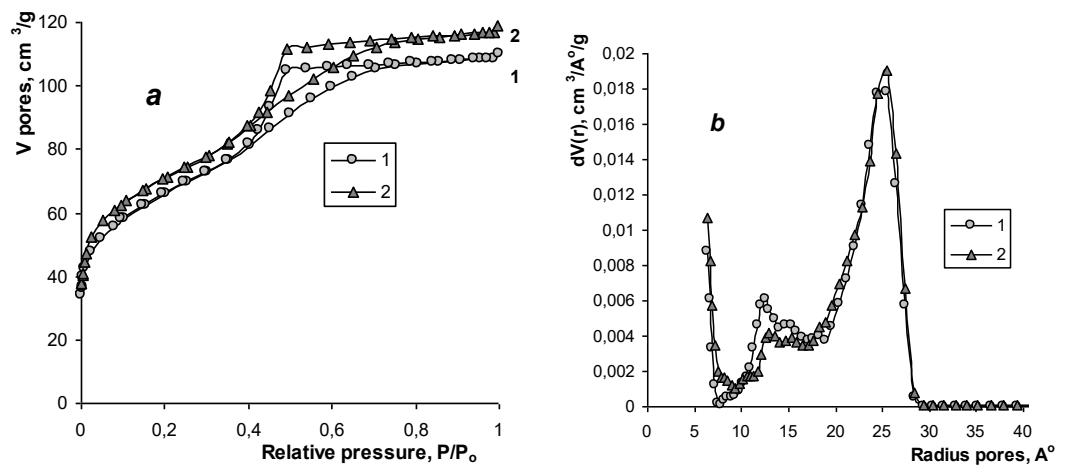

Fig. 3. Low-temperature nitrogen adsorption/ desorption isotherms $(a)$ and the nature of the pore size distribution of the radiuses $(b)$ for the samples $\mathrm{V}-\mathrm{Zr}-\mathrm{Si}-1$ and $\mathrm{V}-\mathrm{Zr}-\mathrm{Si}(\mathrm{Ti})-2$ dried at $130^{\circ} \mathrm{C}$ and calcined at $450^{\circ} \mathrm{C}$
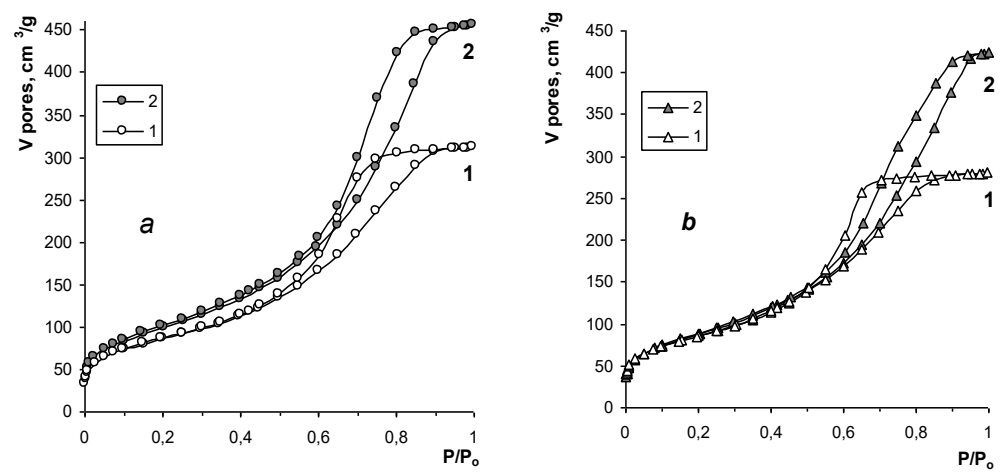

Fig. 4. Low-temperature $\mathrm{N}_{2}$ adsorption isotherms of $\mathrm{V}-\mathrm{Zr}$-Si (a) and $\mathrm{V}-\mathrm{Zr}-\mathrm{Si}$ ( $\mathrm{Ti})(b)$ hydrogels, which are subjected to hydrothermal treatment at $250^{\circ} \mathrm{C}-1$, then decanted with alcohol -2 and then dried at $130^{\circ} \mathrm{C}$ and calcined at $450^{\circ} \mathrm{C}$

The spacious order in the distribution of pores by the size of radiuses of samples after their HTT and decantation with ethanol also changes. The micropores disappear, the radius of the mesopores increases and their size distribution becomes close to uniform (Fig. 5). The specific surface area of the catalysts increases on $50 \sim 70 \mathrm{~m}^{2} / \mathrm{g}$, the pore volume 
in 2,5 - 3 times, the diameter of the mesopores - to $7 \mathrm{~nm}$. At decanting by ethanol, the volume pores increases by another 1,5 times, a specific surface area of $\mathrm{V}-\mathrm{Zr}-\mathrm{Si}$ - on $50 \mathrm{~m}^{2} / \mathrm{g}$ and the diameter of the mesopores becomes more than $8 \mathrm{~nm}$ (table). However, despite the narrower and more uniform distribution of pores by the size of the radiuses at the sample V-Zr-Si (Ti), it is more sharply violated after decantation with alcohol and its specific surface becomes lower, than that of $\mathrm{V}-\mathrm{Zr}-\mathrm{Si}$.
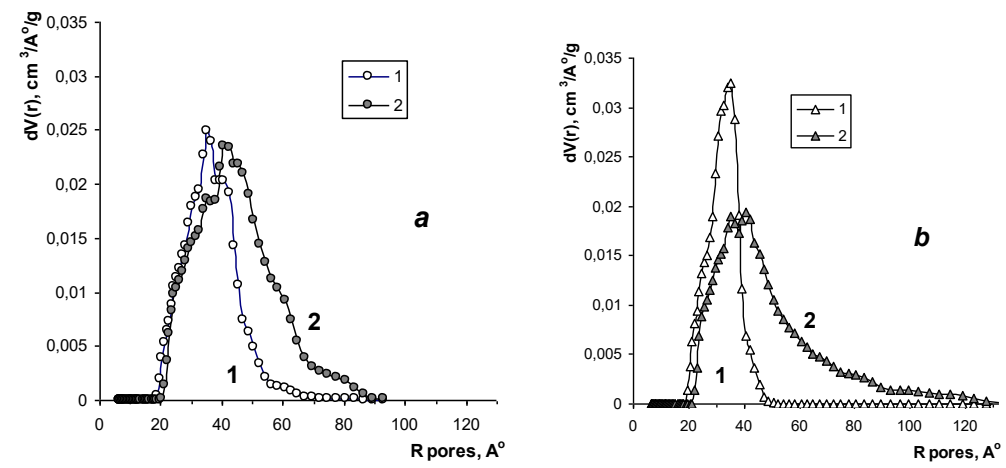

Fig. 5. Calculation of pore size distribution by radiuses by DFT method for $\mathrm{V}-\mathrm{Zr}-\mathrm{Si}(a)$ and $\mathrm{V}-\mathrm{Zr}-\mathrm{Si}$ ( Ti) (b) hydrogels subjected to hydrothermal treatment at $250{ }^{\circ} \mathrm{C}-1$, then decanted with alcohol -2 and after both samples are dried and calcined

This affects the change in the catalytic characteristics of the compared systems (Fig. 6). It can be seen that $\mathrm{V}-\mathrm{Zr}-\mathrm{Si}$ (Ti), which is not subject to HTT, is noticeably more active than the $\mathrm{V}-\mathrm{Zr}-\mathrm{Si}$ sample, which does not contain titanium in the structure. After the HTT, the yields of the obtained propylene on these catalysts are almost compared. But after decantation with alcohol, the value of $\mathrm{Y} \mathrm{C}_{3} \mathrm{H}_{6}$ on $\mathrm{V}-\mathrm{Zr}-\mathrm{Si}$ (Ti) exceeds that obtained on $\mathrm{V}-\mathrm{Zr}-\mathrm{Si}$ only at relatively low reaction temperatures. Such a phenomenon could be explained by the removal of titanium ions from the structure of the support during the HTT or during decantation with alcohol. It is known ${ }^{48}$, that the hydrolytic stability of SiTi bonds in mesoporous titanosilicates is non high.

48 Халдеева О.А., Трухан Н.Н. Мезопористые титан-силикаты как катализаторы процессов жидкофазного селективного окисления органических соединений. Успехи химии. 2005. Т. 75, № 5. С. 460-483. 

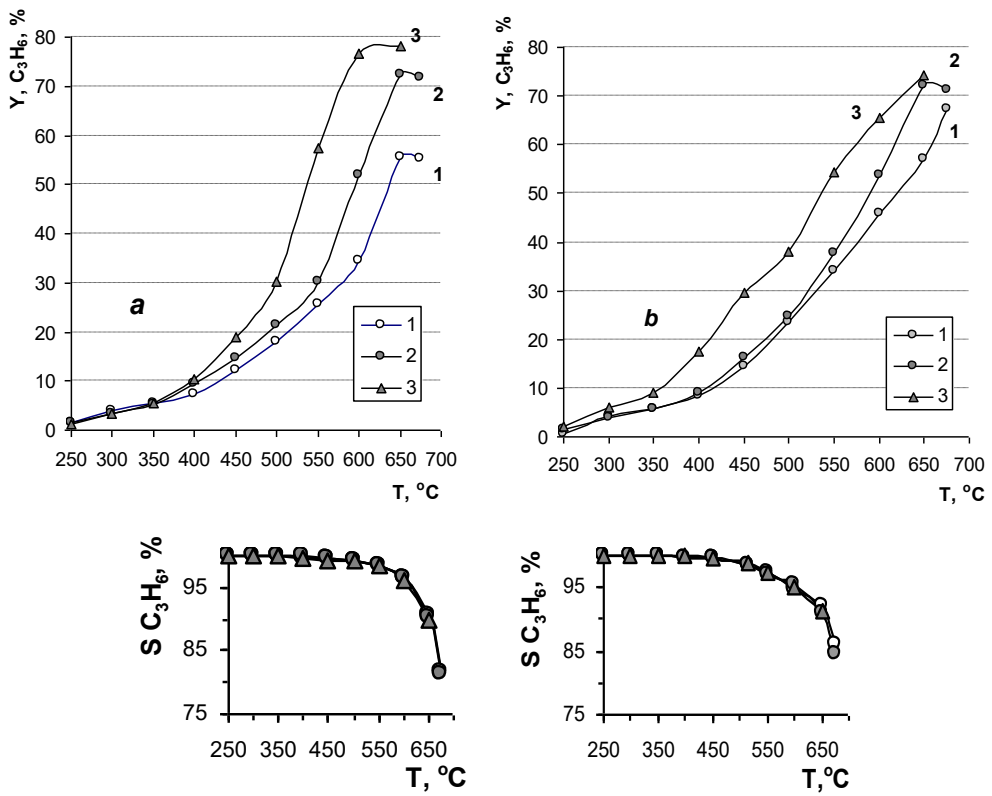

Fig. 6. The yield and selectivity of formation propylene in dehydrogenation of propane on catalysts of $\mathrm{V}-\mathrm{Zr}-\mathrm{Si}(a)$ and $\mathrm{V}-\mathrm{Zr}-\mathrm{Si}(\mathrm{Ti})(b)$, obtained by diffusion of vanadium into the matrix zirconium silicate hydrogel and then: dried at $130{ }^{\circ} \mathrm{C}$ and calcined at $450{ }^{\circ} \mathrm{C}-1$, previously hydrothermally treated at $250{ }^{\circ} \mathrm{C}-2$, after HTT is decanted by ethanol -3 . The reaction mixture is $7 \% \mathrm{C}_{3} \mathrm{H}_{8}$ in argon. Contact time $-3.5 \mathrm{~s}$

The selectivity of propylene formation in all samples (inserts in Fig. $6 \mathrm{a}, \mathrm{b}$ ) is almost the same and is close to $100 \%$ up to a reaction temperature of $500^{\circ} \mathrm{C}$. Then it gradually decreases to a level of $\sim 90 \%$ with increasing temperature to $650{ }^{\circ} \mathrm{C}$. In this case, the yield of propylene in this temperature range increases, since the degree of conversion of propane increases, despite the inevitable deposition of coke on the surface of the catalysts. This may be due to the fact that, according to the authors of ${ }^{49}$, coke on the surface of vanadium oxide

${ }^{49}$ Sokolov S., Stoyanova M., Rodemerck U., Linke D., Kondratenko E.V. Effect of support on selectivity and on-stream stability of surface $\mathrm{VO}_{\mathrm{x}}$ species in nonoxidative propane. Catal. Sci. Technol. 2014. V. 4. P. 1323-1332. URL : https://doi.org/10.1039/C3CY01083J. 
catalysts on acid supports forms less active sites than $\mathrm{VO}_{\mathrm{x}}$, whichare involved in the activation of propane and increase its conversion. In this work it was showed also, that the catalysts exhibited excellent ability to restore their initial activity after $2 \mathrm{~h}$ of oxidative regeneration at $550^{\circ} \mathrm{C}$. In this our work, the regeneration of catalysts after DHP was carried out by their slow cooling in an air stream in an inertial reactor furnace from $650-675^{\circ} \mathrm{C}$ to room temperature. This treatment restored the initial color and structure of the catalysts and almost completely returned their catalytic activity.

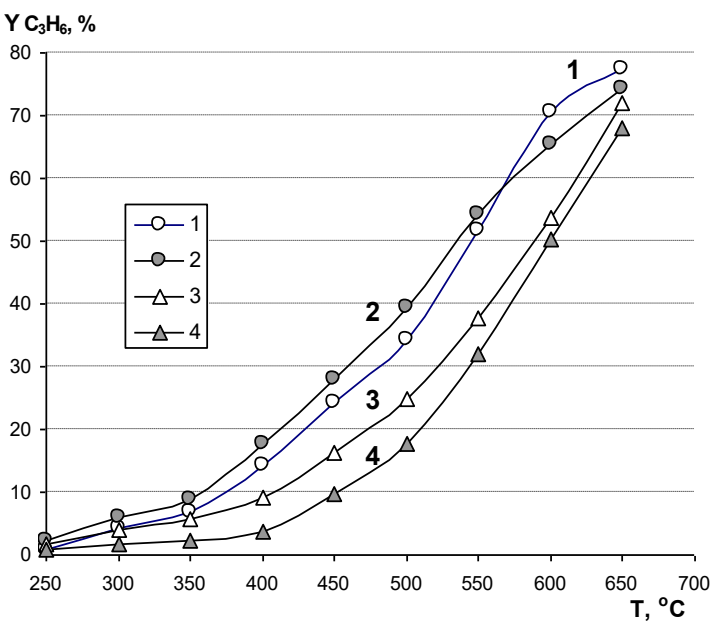

Fig. 7. The propylene yield in the process DHP on catalysts $\mathrm{V}-\mathrm{Zr}-\mathrm{Si}-1$ and $\mathrm{V}-\mathrm{Zr}-\mathrm{Si}(\mathrm{Ti})-2$, obtained during under HTT and decantation with ethanol; $\mathrm{V}-\mathrm{Zr}-\mathrm{Si}(\mathrm{Ti})$ under $\mathrm{HTT}-3$; and $10 \% \mathrm{~V}_{2} \mathrm{O}_{5} / \mathrm{Ti}-\mathrm{MCM}-41-4$

The average yields of propylene obtained on these catalysts, after several cycles of reaction and regeneration, are shown in Fig. 7. They are compared with a sample obtained by HTT without alcohol and a catalyst with the same amount of vanadium oxide $-10 \mathrm{wt}$. \%, supported on a titanosilicate ordered mesoporous system with hexagonal packing of homogeneous cylindrical mesopores - Ti-MCM-41, obtained by 
hydrothermal synthesis ${ }^{50}$. As can be seen, the development of the porous structure of zirconium silicates obtained by the sol-gel method, using the subsequent hydrothermal treatment and decantation with ethanol, can significantly increase the yield of propylene on the supported vanadium oxide in the process of DHP to propylene and lower the temperature when it reaches its maximum values. On fig. 8, the change in the range of size and pore volume of the studied catalysts is compared graphically.

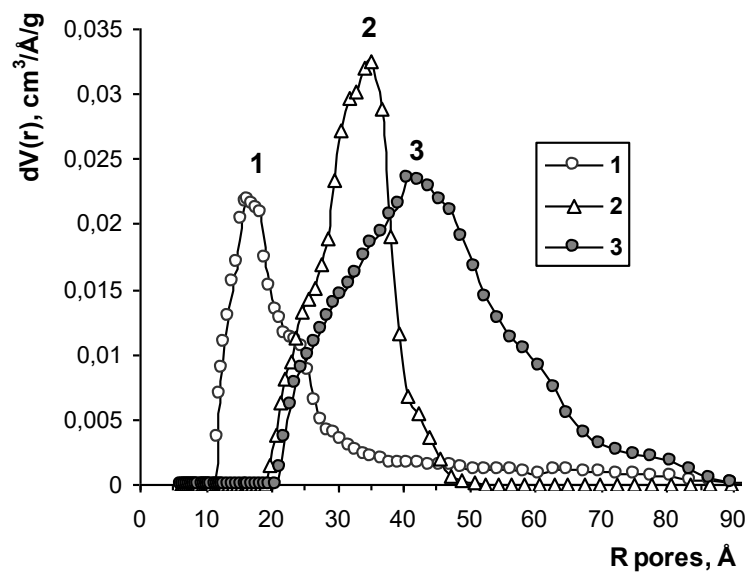

Fig. 8. Comparison of the pore size distribution of radiuses, calculated by the DFT method for catalysts: $10 \% \mathrm{~V}_{2} \mathrm{O}_{5} / \mathrm{Ti}-\mathrm{MCM}-41-1$, $\mathrm{V}-\mathrm{Zr}-\mathrm{Si}(\mathrm{Ti})-2$, obtained during under HTT and $\mathrm{V}-\mathrm{Zr}-\mathrm{Si}-3$, obtained under HTT and decantation with ethanol

$\mathrm{In}^{51}$, previously suggested that for the effective operation of the $\mathrm{V}_{2} \mathrm{O}_{5}$ / Ti-MCM-41 catalyst both in the process of dehydrogenation and oxidative dehydrogenation of propane, it is necessary to ensure the optimal number of active interactions of propane and the formed propylene with active catalytic sites on surface of the walls of

${ }^{50}$ Редькина А.В., Коновалова Н.Д., Хоменко К.Н. Дегидрирование пропана на $\mathrm{V}_{\mathrm{x}} \mathrm{O}_{\mathrm{y}} / \mathrm{H}-\mathrm{Ti}-\mathrm{MCM}-41$. Химия, физика и технология поверхности. 2014. Т. 5, № 2. С. 174-189.

${ }^{51}$ Редькина А.В., Коновалова Н.Д., Хоменко К.Н. Дегидрирование пропана на $\mathrm{V}_{\mathrm{x}} \mathrm{O}_{\mathrm{y}} / \mathrm{H}-\mathrm{Ti}-\mathrm{MCM}-41$. Химия, физика и технология поверхности. 2014. Т. 5, № 2. C. 174-189. 
mesopores, which causing activation of molecules with the continuation of the reaction on the surface and in the pore volume. This is facilitated by the optimal ratio between the acidity of the active sites, estimated, for example, from the adsorption of ammonia - A, in $\mathrm{ml} / \mathrm{g}$, and the volume of catalyst mesopores - $\mathrm{V}_{\mathrm{DFT}}(\mathrm{ml} / \mathrm{g})$. The highest yields of propylene are in a certain optimal range of $\mathrm{A} / \mathrm{V}_{\mathrm{DFT}}$ variation.

The data obtained in this work confirm this assumption. The acidity of mixed $\mathrm{ZrO}_{2} \mathrm{SiO}_{2}$ oxides ${ }^{52}$ is significantly higher than that of TiMCM-41. Therefore, in order to avoid strong adsorption of propylene, which is of a basic nature, on the acid sites of the catalyst and its destruction, the volume and pore diameter of the support $\mathrm{ZrO}_{2} \mathrm{SiO}_{2}$ should be much larger than that of Ti-MCM-41, in order to obtain a high yield of $\mathrm{C}_{3} \mathrm{H}_{6}$ during the propane dehydrogenation. That is obtained in practice. The increased acidity of $\mathrm{ZrO}_{2} \mathrm{SiO}_{2}$, providing easier activation of neutral propane, can contribute to lowering the temperature of obtaining high yields of propylene.

It is desirable to compare the effect of the composition and structure of catalysts on the course of the DHP process under similar conditions. In article $^{53}$, authors noted that tests of the catalytic activity of $\mathrm{Pt}-\mathrm{Sn} / \mathrm{Al}_{2} \mathrm{O}_{3}$ were carried out under conditions close to industrial, namely, at an hourly average velocity of the gas mixture per unit mass of catalyst (weight hour space velocity) - WHSV $=2 \mathrm{~h}^{-1}$. The reaction mixture consisted of a streams of propane and hydrogen in the ratio $\mathrm{H}_{2} / \mathrm{HC}=1$ diluted with nitrogen (not indicated to what extent) was supplied at a rate of $18 \mathrm{ml} / \mathrm{min}$ per $1 \mathrm{~g}$ of catalyst, with a specific surface area of $196 \mathrm{~m}^{2} / \mathrm{g}$ and pore volume in $0.5 \mathrm{~cm}^{3} / \mathrm{g}$. As a result, at $600^{\circ} \mathrm{C}$ with a propane conversion of $\sim 40 \mathrm{~mol}$. $\%$ and propylene selectivity of $\sim 90$ mol. $\%$ its yield in $\sim 35 \mathrm{~mol} \%$ was obtained. These results are typical of the Oleflex process and are consistent with those reported in ${ }^{54}$.

${ }^{52}$ Bosman, H.J.M., Kruissink, E.C., Van der Spoel, J., Van den Brink, F.: Characterization of the acid strength of $\mathrm{ZrO} 2 \mathrm{SiO} 2$ mixed oxides. J. Catal. 1994, V. 148. P. 660-672. URL : https://doi.org/10.1006/jcat.1994.1253.

${ }^{53}$ Sahebdelfar S., Tahriri Zangeneh F. Dehydrogenation of Propane to Propylene Over Pt-Sn/ $/ \mathrm{Al}_{2} \mathrm{O}_{3}$ Catalysts: The influence of operating conditions on product selectivity. Iranian J.Chem. Eng. 2010. V. 7, №. 2. P. 51-57.

${ }_{54}^{54}$ Макарян И.А., Рудакова М.И., Савченко В.И. Промышленные процессы целевого каталитического дегидрирования пропана в пропилен. Междунар. научн. журнал «Альтернативная энергетика и экология». 2010. Т. 86, № 6. C. $67-81$. 
The data article $\mathrm{e}^{55}$ it is more correctly to compared with our results. In this study, the reaction mixture contained 40 vol. $\% \mathrm{C}_{3} \mathrm{H}_{8}, 60$ vol. $\% \mathrm{~N}_{2}$ and it was fed into the reactor at a rate of $3 \mathrm{ml} / \mathrm{min}$. Thus, $1.2 \mathrm{ml} / \mathrm{min}$ of $\mathrm{C}_{3} \mathrm{H}_{8}$ entered the reactor. In our work, a mixture, containing 7 vol. $\%$ $\mathrm{C}_{3} \mathrm{H}_{8}$ in argon, at a feed rate of $18 \mathrm{ml} / \mathrm{min}$ to the catalyst, gave the same stream of pure propane - $1.26 \mathrm{ml} / \mathrm{min}$. On fig. 9, the catalytic characteristics of the V-Zr-Si (Ti) catalyst, obtained under HTT and decantation by alcohol, after several cycles of its work and regeneration in DHP, are compared with the data of the catalytic parameters of the samples, which studied in the cited paper.

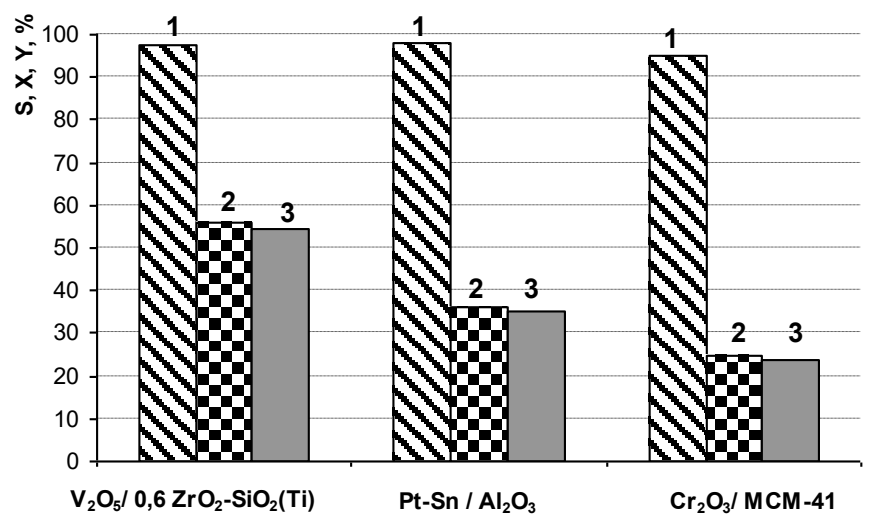

Fig. 9. Comparison of the degree of conversion of propane -2 , the selectivity of the formation of propylene -1 and its yield -3 during the propane dehydrogenation at $550{ }^{\circ} \mathrm{C}$ on industrial catalyst of the Oleflex process - $\mathrm{Pt}-\mathrm{Sn} / \mathrm{Al}_{2} \mathrm{O}_{3}$ and $\mathrm{Cr}_{2} \mathrm{O}_{3} / \mathrm{MCM}-41$, according data to ${ }^{56}$ and on the obtained catalyst $\mathrm{V}_{2} \mathrm{O}_{5}-\mathrm{ZrO}_{2}-\mathrm{SiO}_{2}(\mathrm{Ti})$

Sokolov S., Stoyanova M., Rodemerck U., Linke D., Kondratenko E.V. Comparative study of propane dehydrogenation over $\mathrm{V}-, \mathrm{Cr}-$, and Pt-based catalysts: Time on-stream behavior and origins of deactivation. J. Catal. 2012. V. 293. P. 67-75. URL : http://dx.doi.org/10.1016/j.jcat.2012.06.005.

56 Sokolov S., Stoyanova M., Rodemerck U., Linke D., Kondratenko E.V. Comparative study of propane dehydrogenation over $\mathrm{V}-, \mathrm{Cr}-$, and Pt-based catalysts: Time on-stream behavior and origins of deactivation. J. Catal. 2012. V. 293. P. 67-75. URL : http://dx.doi.org/10.1016/j.jcat.2012.06.005. 
It can be seen that with the same high selectivity of propylene formation, its yield on the obtained vanadium-zirconium-silicate catalyst is significantly higher than on the well-known industrial catalysts of the Oleflex and Catofin processes. Facing, the manufacturability of the process for producing of the $\mathrm{V}_{2} \mathrm{O}_{5}-\mathrm{Zr}$-Si catalyst, the relative cheapness of its composition, ease of regeneration, it can assume, that in the future it can serve as a replacement for the depleted industrial catalysts of DHP processes

\section{CONCLUSIONS}

The vanadium oxide used in this catalyst works stably, both in the oxidized and in the reduced state, and is also the active phase of the developed catalysts for the exothermic, energy-saving process of oxidative dehydrogenation of propane. Therefore, the regeneration of this catalyst during DHP can be a simple transition to its ODHP without stopping the dehydrogenation process itself. Applied cheap technology for the synthesis of a support of such a catalyst from accessible salts of elements with obtain solid spherical granules, allows its use in a fluidized bed of catalyst, allowing the conducting, of reaction in an unsteady mode with an increase in the yield of the product.

Currently, new propylene production plants are being built in the United States due to increased production of propane, which was the result of an increase in gas production at the country's shale deposits ${ }^{57}$. Companies of China are also very interested in propane dehydrogenation (PDH) technology used to produce propylene. UOP LLC Honeywell Company announced that its second propylene production unit using propane dehydrogenation technology using the C3 Oleflex process was commissioned in China in Shaoxing, Zhejiang ${ }^{58}$. Zhejiang Shaoxing Sanjin Petrochemical Co., Ltd in this factory will produce 450,000 MTA of propylene and 600,000 tons of polypropylene per year. UOP LLC Honeywell Company (NYSE: HON) also announced on June 11, 2015 that its C3 Oleflex process will be used in Poland by Grupa Azoty and will produce 400,000 metric tons of high-quality propylene per year, sufficient to support the production of nearly 11 million vehicles in year.

${ }^{57}$ Синицин М.В. Влияние «сланцевой революции» в США на американскую и мировую экономику. С. 22-26 в кн. Перестройка мировых энергетических рынков: Возможности и вызовы для России / Под ред С.В. Жукова. Москва : ИМЭМОРАН, 2015. 152 с.

${ }^{58}$ UOP's PP plant using C3 Oleflex technology starts in China. February 03, 2015 (China). URL : http://www.fibre2fashion.com>. 
The new block in Szczecin - the region of Poland, planned to launch in $2019^{59}$.

Since Ukraine has the leading zirconium reserves in the world, the production of catalysts based on it and the replacement of expensive platinum-containing catalysts in Oleflex technology would be a promising task.

\section{SUMMARY}

It has been analysis of the challenges facing the industry of targeted catalytic dehydrogenation of propane to propylene, which is valuable intermediate in the chemical industry and serves as the basis for the production of many chemical products. It has been consider the most promising catalysts for this process. Using direct sol-gel synthesis, spherically granulated micro-mesoporous zirconium silicate hydrogels, also modified with titanium dioxide, were obtained from the available salts of the elements. The supported vanadium oxide catalysts were obtained by impregnating them with a vanadyl sulfate salt. It was shown that their preliminary hydrothermal treatment and decantation with alcohol makes it possible to increase the specific surface area of the catalysts, the volume and width of their pores, and form a developed mesoporous structure. This leads to a significant increase in the yield of propylene and allows to lowering the temperature for to obtaining its high values. It was shown that the obtained catalysts can in the prospect replace expensive or toxic Pt- and Cr-containing industrial catalysts. The methods used are scanning electron microscopy with microprobe analysis, X-ray phase analysis, nitrogen adsorption / desorption, and gas chromatography.

\section{REFERENCES}

1. Брагинский О.Б. Мировая нефтехимическая промышленность. Москва : Наука, 2003, 556 с.

2. Новый справочник химика и технолога. Сырье и продукты органических и неорганических веществ. Часть II. СПб. НПО «Профессионал», 2007, 1144 с.

3. Макарян И.А., Рудакова М.И., Савченко В.И. Промышленные процессы целевого каталитического дегидрирования пропана в пропилен. Междунар. научн. журнал «Альтернативная энергетика и экология». 2010. Т. 86, № 6. С. 67-81.

59 Honeywell UOP to Power Europe's Largest Production Unit for Plastics Building Block. June 11, 2015. URL : http://www.uop.com. 
4. Vora B.V. Development of Dehydrogenation Catalysts and Processes. Top. Catal. 2012. V. 55. P.1297-1308. DOI:10.1007/s11244012-9917-9.

5. Sattler J.H.B., Ruiz-Martinez J., Santillan-Jimenez E., Weckhuysen B.M. Catalytic Dehydrogenation of Light Alkanes on Metals and Metal Oxides. Chem. Rev. 2014. V. 114, №. 20. P. 1061310653. URL : https://doi.org/10.1021/cr5002436|.

6. Nawaz Z. Light alkane dehydrogenation to light olefin technologies: A comprehensive review.Rev. Chem. Eng. 2015. V. 31, № 5. P. 413-436. URL : https://doi.org/10.1515/revce-2015-0012.

7. McFarland E. Unconventional Chemistry for Unconventional Natural Gas. Science. 2012. V. 338. P. 340-342. DOI: 10.1126/science. 1226840 .

8. Bhatt B.L., Kirner J.F., Rao P. and Schwartz W.A. Catalytic dehydrogenation reactor cycle. Pat. US 4581339, Publ. Apr. 08, 1986.

9. Bricker J.C., Jan D.-Y., Foresman J.M. Dehydrogenation catalyst composition. Pat. US 4914075, Publ. Apr. 03, 1990.

10. Brinkmeyer F.M., Savage K.B. and Bridges S.D. Dehydrogenation process control Pat US. 5243122, Publ. Sept. 07, 1993.

11. Iezzi R., Bartolini A., Buonomo F., Kotelnikov G. and Bespalov V. Process for obtaining light olefins by the dehydrogenation of the corresponding paraffins Pat. US 6362385, Publ. March 26, 2002.

12. Heineke D., Baier M., Demuth D. and Harth K. Method and catalyst for producing olefins, in particular propylenes, by dehydrogenation. Pat. US 6576804, Publ. June 10, 2003.

13. UOP's PP plant using C3 Oleflex technology starts in China. February 03, 2015 (China). URL : http://www.fibre2fashion.com > News.

14. Ruettinger W. and Jacubinas R. Chromia alumina catalysts for alkane dehydrogenation. Pat. US 8895468, Publ. Novem. 25, 2014.

15. Sokolov S., Stoyanova M., Rodemerck U., Linke D., Kondratenko E.V. Comparative study of propane dehydrogenation over $\mathrm{V}-$, Cr-, and Pt-based catalysts: Time on-stream behavior and origins of deactivation. J. Catal. 2012. V. 293. P. 67-75. URL : http://dx.doi.org/10.1016/ j.jcat.2012.06.005.

16. Sokolov S., Stoyanova M., Rodemerck U., Linke D., Kondratenko E.V. Effect of support on selectivity and on-stream stability of surface $\mathrm{VO}_{\mathrm{x}}$ species in non-oxidative propane. Catal. Sci. Technol. 2014. V. 4. P. 1323-1332. URL : https://doi.org/10.1039/C3CY01083J.

17. Sokolov S., Bychkov V.Yu., Stoyanova M. Rodemerck U., Bentrup U., Linke D., Tyulenin Y.P., Korchak V.N., Kondratenko E.V. Effect of VOx Species and Support on Coke Formation and Catalyst Stability in Nonoxidative Propane Dehydrogenation. ChemCatChem. 
2015. V. 7. P. 1691-1700. URL : https://doi.org/10.1002/ cctc. 201500151.

18. Зажигалов В.А., Коновалова Н.Д., Редькина А.В., Хоменко К.Н. Сравнительное исследование дегидрирования пропана на $\mathrm{VO}_{\mathrm{x}} / \mathrm{MCM}-41$ и $\mathrm{VO}_{\mathrm{x}} / \mathrm{Ti}-\mathrm{MCM}-41$ с получением пропилена и водорода. Укр. хім. журн. 2013. V. 79. № 11. С. 63-72.

19. Cavani F., Ballarini N., Cericola A. Oxidative dehydrogenation of ethane and propane: How far from commercial implementation? Catal. Today. 2007. V. 127. P.113-131. URL : https://doi.org/10.1016/ j.cattod.2007.05.009.

20. Liu G., Zhao Z.-J., Wu T., Zeng L., Gong J. Nature of the Active Sites of $\mathrm{VO}_{x} / \mathrm{Al}_{2} \mathrm{O}_{3}$ Catalysts for Propane Dehydrogenation. ACS Catal. 2016.V. 6, № 8. P. 5207-5214. URL : http:// DOI: 10.1021/acscatal.6b00893.

21. Yamaguchi T. Application of $\mathrm{ZrO}_{2}$ as a catalyst and a catalyst support. Catal. Today. 1994. V. 20. P. 199-217. URL : https://doi.org/10.1016/0920-5861(94)80003-0.

22. DeRossi S.. Ferraris,G., Fremoiotti S.,Garrone E..Ghiotti G., Campa M.C., IndovinaV. Propane Dehydrogenation on Chromia/Silica and Chromia/Alumina Catalysts. J.Catal. 1994, V. 148. P. 36-46. URL : https://doi.org/10.1006/jcat.1994.1183.

23. Cimino A., Cordischi D., DeRossi S., Ferraris G., Gazzoli D., Indovina V., Minelli G., Occhiuzzi M., Valigi M. Studies on chromia/zirconia catalysts I. Preparation and characterization of the system. J.Catal. 1991. V. 127. P. 744-760. URL : https://doi.org/10.1016/0021-9517(91)90196-B.

24. Zhao B.Y., Xu X.P., Ma H.R., Sun D.H., Gao J.M. Monolayer dispersion of oxides and salts on surface of $\mathrm{ZrO}_{2}$ and its application in preparation of $\mathrm{ZrO}_{2}$-supported catalysts with high surface areas. Catal. Letters. 1997. V. 45. P. 237-244. URL : https://doi.org/10.1023/ A:1019048503124.

25. del Monte F., Larsen W., Mackenzie J.D.: J Stabilization of Tetragonal $\mathrm{ZrO}_{2}$ in $\mathrm{ZrO}_{2}-\mathrm{SiO}_{2}$ Binary Oxides. Am. Chem. Soc. 2000. V. 83. P. 628-634. URL : https://doi.org/10.1111/j.11512916.2000.tb01243.x.

26. Tanabe K., Yamaguchi T. Acid-base bifunctional catalysis by ZrOa and its mixed oxides. Catal. Today. 1994. V. 20. P. 185-197. URL : https://doi.org/10.1016/0920-5861(94)80002-2.

27. Fujdala K.L., Tilley T.D. Thermolytic molecular precursor routes to $\mathrm{Cr} / \mathrm{Si} / \mathrm{Al} / \mathrm{O}$ and $\mathrm{Cr} / \mathrm{Si} / \mathrm{Zr} / \mathrm{O}$ catalysts for the oxidative dehydrogenation and dehydrogenation of propane. J. Catal. 2003. V. 218. P. 123-134. URL : https://doi.org/10.1016/S0021-9517(03)00141-6. 
28. Otroshchenko T., Bulavchenko O., Thanh H. V., Rabeah J., Bentrup U., Matvienko A., Rodemerck U., Paul B., Kraehnert R., Linke D., Kondratenko E.V. Controlling activity and selectivity of bare $\mathrm{ZrO}_{2}$ in nonoxidative propane dehydrogenation. Appl.Catal. A: Gen. 2019. V. 585. P. 117189-117199. URL : https://doi.org/10.1016/j.apcata.2019.117189.

29. Jeon N., Choe H., Jrong B., Yun Y. Cu-promoted zirconia catalysts for non-oxidative propane dehydrogenation. Appl.Catal. A: Gen. 2019. V. 586. P. 117211117219. URL : https://doi.org/10.1016/j.apcata.2019.117211.

30. Редькина А.В., Коновалова Н.Д., Кравченко Н.В., Стрелко В.В. Дегидрирование пропана в пропилен на $\mathrm{V}_{2} \mathrm{O}_{5}$, нанесенном на микро-мезопористую систему оксидов $\mathrm{ZrO}_{2}-\mathrm{SiO}_{2}-\mathrm{TiO}_{2}$. Укр. xiм. журн. 2018. Т. 84, № 7. С. 43-59.

31. Яковлев И.І., Стрелко В.В., Кравченко М.В. Золь-гель спосіб одержання сферично гранульованого високо поруватого цирконій силікату. Опис до патенту на корисну модель. UA 105999 U, опубл. 10.04.2016, Бюл. № 7 .

32. Редькіна А.В., Коновалова Н.Д., Стрелко В.В. Способ одержання каталізатора дегідрування пропану в пропілен. Опис до патенту на корисну модель UA 131758 U, опубл. 25.01.2019, бюл. № 2.

33. Koyano K.A., Tatsumi T. Synthesis of titanium-containing MCM-41. Microporous Material. 1997. V. 10: P. 259-271. URL : https://doi.org/10.1016/S0927-6513(97)00016-3.

34. Selvam P., Dapurkar S.E. The effect of vanadium sources on the synthesis and catalytic activity of VMCM-41. J. Catal. 2005. V. 229. P. 64-71. URL : http://dx.doi.org/10.1016/j.jcat.2004.10.005.

35. Raju V., Jaenicke S., Chuah G.-K. Effect of hydrothermal treatment and silica on thermal stabilityë and oxygen storage capacity of ceria-zirconia. Appl. Catal. B. 2009. V. 91. P. 92-100. URL : https://doi.org/10.1016/j.apcatb.2009.05.010.

36. He X., Zhang H., Li Y., Hong Ch., Zhao J. Preparation and Structural Characterization of $\mathrm{SiO}_{2}-\mathrm{ZrO}_{2}$ Aerogels. Key Eng. aterials. 2007. V. 336-338. P. 2282-2285. URL : https://doi.org/10.4028/ www.scientific.net/KEM.336-338.2282.

37. Bosman, H.J.M., Kruissink, E.C., Van der Spoel, J., Van den Brink, F. Characterization of the acid strength of $\mathrm{ZrO}_{2}-\mathrm{SiO}_{2}$ mixed oxides. J. Catal. 1994, V. 148. P. 660-672. URL : https://doi.org/10.1006/jcat.1994.1253.

38. Li M., Feng Z., Xiong G. Ying P., Xin Q., and Li C. Phase Transformation in the Surface Region of Zirconia Detected by UV Raman Spectroscopy. J. Phys. Chem. B. 2001. V.105. P. 8107-8111. URL : https://doi.org/10.1021/jp0105261. 
39. Sing K.S.W., Everett D.H., Haul R.A.W., Moscou L., Pierotti R.A., Rouquerol J. and Siemieniewska T. Reporting Physisorption Data for Gas/Solid Systems with Special Reference to the Determination of Surface Area and Porosity. Pure and Applied Chemistry. 1985. V. 57, No. 4. P. 603-619. URL : https://doi.org/10.1351/pac198254112201.

40. Халдеева О.А., Трухан Н.Н. Мезопористые титан-силикаты как катализаторы процессов жидкофазного селективного окисления органических соединений. Успехи химии. 2005. Т. 75, № 5. С. 460-483.

41. Редькина А.В., Коновалова Н.Д., Хоменко К.Н. Дегидрирование пропана на $\mathrm{V}_{\mathrm{x}} \mathrm{O}_{\mathrm{y}} / \mathrm{H}-\mathrm{Ti}-\mathrm{MCM}-41$. Химия, физика $и$ технология поверхности. 2014. Т. 5, № 2. С. 174-189.

42. Sahebdelfar S., Tahriri Zangeneh F. Dehydrogenation of Propane to Propylene Over Pt-Sn/ $\mathrm{Al}_{2} \mathrm{O}_{3}$ Catalysts: The influence of operating conditions on product selectivity. Iranian J. Chem. Eng. 2010. V. 7, №. 2. P. 51-57.

43. Синицин М.В. Влияние «сланцевой революции» в США на американскую и мировую экономику. С. 22-26 в кн. Перестройка мировых энергетических рынков: Возможности и вызовы для России. Под ред С.В. Жукова. Москва : ИМЭМОРАН, 2015, 152 с.

44. UOP's PP plant using C3 Oleflex technology starts in China. February 03, 2015 (China). URL : http://www.fibre2fashion.com».

45. Honeywell UOP to Power Europe's Largest Production Unit for Plastics Building Block. June 11, 2015. URL : http://www.uop.com.

\section{Information about authors:} Redkina A. V.,

Candidate of Chemical Sciences, Senior Researcher of the Institute of Sorption and Problems of Endoecology National Academy of Sciences of Ukraine 13, Gen. Naumova St., Kyiv, 03164, Ukraine

Konovalova N. D.,

Candidate of Chemical Sciences, Senior Researcher of the Institute of Sorption and Problems of Endoecology

National Academy of Sciences of Ukraine 13, Gen. Naumova St., Kyiv, 03164, Ukraine 